\title{
16 Motion to and Motion through: Evidence from a Multilingual Corpus ${ }^{1}$
}

Thomas Egan

Hedmark University College

\section{Introduction}

Over the course of the last twenty years, there has been a considerable amount of comparative research into the coding of motion events in various languages (see, for instance, Filipović \& Jaszczolt 2012, Hickmann \& Robert 2006, Viberg 1998, 2003, 2013). This research has led to a reassessment and subsequent refinement of Talmy's typology (I99I, 2000), according to which languages are said to be either satellite-framed or path-framed. According to Talmy, satellite-framed languages, such as English, tend to code manner of motion in the verb and path of motion in an adverbial (particle) in self-motion constructions, i.e constructions in which it is the syntactic subject which moves, as in He walked to work. Path-framed languages, such as Spanish, tend to code path in the verb and manner, if at all, in an adverbial. In recent years this typology has been expanded to include so-called equipollent framing, found in various serial verb languages (Slobin 2006). The clear dichotomy proposed by Talmy has also been nuanced by scholars who point to the co-existence of several patterns of framing in one and the same language. Kopecka (2006) and Pourcel and Kopecka (2005), for example, propose such a hybrid situation for French.

In this chapter I take a fresh look at satellite- and path-framing in English and French in a comparative study of codings of self-motion predications

${ }^{1}$ I would like to thank the editors for inviting me to contribute to this volume in honour of Nils-Lennart. I would also like to thank two anonymous referees for helpful and insightful comments on my chapter.

How to cite this book chapter:

Egan, T. 20I 5. Motion to and Motion through: Evidence from a Multilingual Corpus. In: Shaw, P., Erman, B., Melchers, G. and Sundkvist, P. (eds) From Clerks to Corpora: essays on the English language yesterday and today. Pp. 285-302. Stockholm: Stockholm University Press. DOI: http://dx.doi.org/Io.I6993/bab.p License: CC-BY. 
in which the path either traverses a space or area ('through-ness') or leads up to a goal ('to-ness'). The reason for choosing these two path types is that French in particular is said to avoid the use of manner verbs with telic actions in general (Aske 1989: 6) and actions involving boundary-crossing in particular (Cappelle 20I 2: I 89). In order to carry out a comparison of types of predication in two languages one needs a reliable tertium comparationis (see Jaszczolt 2003, Johansson 2007: 39, Krzeszowski I990: I 5). Much earlier research into the ways in which languages code motion events made use of a tertium comparationis in the form of events in a picture book (such as the Frog story: see Berman \& Slobin I994) or in short video snippets, which are described by participants in the experiment. The Oslo Multilingual Corpus (OMC), provides the tertium comparationis for the present study, where expressions in a source language serve as grounds for the comparison of their translations into two or more languages (see Egan 20I3, Egan \& Rawoens 20I3).

I take as my starting point Norwegian predications in the OMC of self-motion events containing two path prepositions, til (= to) and gjennom (= through), and compare the English and French translations of these predications. In section 2 I introduce the corpus and explain briefly why I consider such a corpus to be suitable for this sort of study. Sections 3 and 4 compare English and French renderings of the notion of 'through-ness' and 'to-ness', as these are coded by the Norwegian prepositions giennom and til. The results of the investigation of the two sorts of path predications are compared in section 5. Finally, section 6 contains a summary and conclusion.

\section{Multilingual corpora as sources of tertia comparationis}

In a comparative study such as the present one, which is based on English and French translations of Norwegian predications, the tertium comparationis is given by the original Norwegian texts. This tertium comparationis can, of course, only be viewed as a guarantor of semantic equivalence between the English and French expressions to the extent that the translators have aimed to convey as much as possible of the meaning of the original texts. My own experience of working with translation corpora has led me to believe that professional translators try to convey as much as possible of the sense of the original text most of the time. One will inevitably come across instances of mistranslation or non-translation, but the former are very rare in the $\mathrm{OMC}$ in my experience, which in itself testifies to the 
quality of the translations in the corpus. More common than mistranslation is the complete omission by a translator of a predication in the original text. In cases where one of two translators whose texts are being compared omits to translate a predication in the source text, one has no grounds for comparing them. Both the translated and non-translated version of this item must accordingly be excluded from the comparative study.

The OMC was compiled under the direction of Stig Johansson (see Johansson 2007). The No-En-Fr-Ge part of the corpus contains texts in four languages, consisting of long extracts from five Norwegian novels translated into English, French and German. For the present study I only looked at the English and French translations. A multilingual corpus has at least two advantages over a bilingual translation corpus. In the first place it allows for the comparison of identical text types, in that both texts being compared are translations, whereas in working with a bilingual translation corpus one is comparing an original text with a translation. Given that translated texts differ from original texts along various parameters, it makes obvious sense to compare one translation to another translation. In the second place, the examination of comparable translations in a multilingual corpus allows us to estimate the overlap between equivalent expressions in the two languages being compared.

My tertium comparationis comprises all Norwegian predications of self-motion events containing the two path prepositions, giennom and til in the OMC. I downloaded all tokens containing the two forms in the corpus, then extracted all tokens coding motion events and finally discarded tokens coding caused motion, by which I mean tokens containing an explicit causer who/which causes someone/something to move along a path (such as 'She drove him to work'). All predications of motion without an explicit causer, in other words all S-V-A sentences, were categorised as coding self-motion, irrespective of the degree of agentivity of the mover. A glance at a bilingual dictionary or contrastive grammar will show that Norwegian giennom codes relations that may be rendered in English by through and in French by à travers, among other prepositions. Similarly, Norwegian til codes relations that may be rendered in English by to and in French by à. My primary interest, however, is not in the correspondences between the Norwegian original and its translations into the other two languages, but in the correspondences between the two sets of translations. To this end, having extracted all the occurrences in the OMC of Norwegian gjennom ( $\mathrm{I}$ I 0 tokens) and til (664 tokens) in self-motion predications, 
the Norwegian originals were set aside and comparisons drawn between the English and French renderings of these predications.

One point that should be made about the data is that Norwegian is a satellite-framed language like English but unlike French. ${ }^{2}$ Moreover, all the original Norwegian tokens contain a path preposition. Slobin (2006: 70) claims that "in translations [...] manner salience follows patterns of the target, rather than source language". If he is correct, the fact that Norwegian is satellite-framed should not affect the results of the comparison, at least as far as coding of manner is concerned. This contention of Slobin's has, however, been disputed by Cappelle (20I 2), who maintains that translations of motion predications will tend to some extent to borrow the form of the original text, irrespective of typological differences between the two languages involved. One should bear this argument in mind in interpreting the data presented in the next two sections.

\section{English and French strategies for coding 'through-ness'}

As mentioned in the previous section, the tertium comparationis for my analysis of 'through-ness' consists of codings in Norwegian of this concept by means of the preposition/particle giennom. The main definition of giennom in Norsk Ordbok, the closest Norwegian equivalent to the $O E D$, is:

$[\mathrm{U}]$ sed about a movement or something perceived as motion which takes place in (within, surrounded by) that which is encoded by the landmark [i.e. the prepositional object] from one end or side all the way to the other, containing the whole landmark from start to finish; (in) from the one side or end and (out) to the other. (Norsk Ordbok 2002, my translation $)^{3}$

\footnotetext{
${ }^{2}$ In fact Norwegian is rather more satellite-framed than English. As a result of the Norman conquest English contains path verbs such as enter and descend, where Norwegian has a combination of a verb and a particle. One reviewer points out that Old English already contained some path verbs of native origin such as stigan which can be used in the sense 'ascend'. This is certainly true, but it is also true of Old Norse, with the verb stiga being cognate with OE stigan, for instance. The point is that the number of such verbs in English increased in Middle English.

3 The original definition reads: "Gjennom el igjennom prep, adv I a) brukt om rørsle el noko oppfatta som rørsle for å uttrykkja at ho går føre seg i (innanfor, omslutta av) det som styringa nemner frå den eine enden, den eine sida heilt ut til (på) den andre, at ho omfattar det som er uttrykt i styringa frå byrjing til slutt; (inn) frå den eine og (ut) til den andre sida el enden av". (Norsk Ordbok 2002)
} 
This definition of Norwegian giennom is very similar to standard definitions of the prototype of through, as described for example by Egan (2012: 44), Lee (200I: 49), Leech (I969: I8I), Lindstromberg (I998: 3I), and Tyler and Evans (2003: 219). The similarity in the prototypical senses of Norwegian giennom and English through is reflected in the number of occurrences of through in the English translations, $8 \mathrm{I}$ of which $(74 \%)$ contain the form. This prototypical sense of through is illustrated here by examples (I) and (2), with the path in italics. ${ }^{4}$

(I) a. We began to walk slowly through the galleries, and up to the first floor. ( $\left.\mathrm{JG}_{3} \mathrm{TE}\right)$

b. Nous déambulâmes un moment à travers les salles, puis montâmes au premier étage. (JG3TF)

(2) a. I suggested I could walk with him through the Retiro Park. (JG3 TE)

b. Je proposai de l'accompagner à travers le Retiro. (JG3 3 TF)

The French versions of (I) and (2) both contain the preposition à travers. The prototypical sense of this preposition, according to the definition in Dictionnaire de l'Académie française, differs from its English counterpart in emphasising the central portion of the landmark, the space or area through which the path extends (often referred to as a 'container' in the literature), backgrounding the elements of entrance and exit.

À TRAVERS, AU TRAVERS DE, locative preposition. Going from one side to the other, crossing: À travers is mostly used to code an open or free passage; Au travers de on the other hand is used to code a passage made between obstacles, or crossing or penetrating an obstacle; however this distinction is not rigorously observed. (Dictionnaire de l'Académie française, $8^{\mathrm{e}}$ edition: my translation) ${ }^{5}$

${ }_{4}$ The English and French versions of all tokens are cited in the text itself. The first part of the code, 'JG3' in (I) for example, refers to the text in the OMC from which the example has been taken. 'TE' stands for translated text in English, 'TF' translated text in French. The corresponding Norwegian originals are listed in an appendix.

5 The $8^{\text {th }}$ rather than the $9^{\text {th }}$, and most recent, edition of the dictionary has been used, as the online version of the $9^{\text {th }}$ edition had not reached the letter ' $t$ ' at the time of writing. The original definition reads “À TRAVERS, AU TRAVERS DE, loc. prép. En allant d'un bord à l'autre, en traversant. À travers se dit principalement pour désigner un Passage vide, libre; $A u$ travers de se dit plutôt, au contraire, pour désigner un Passage qu'on se fait entre des obstacles, ou en traversant, en pénétrant un obstacle; mais cette distinction n'est pas toujours rigoureusement observe" (Dictionnaire de l'Académie française, $8^{\mathrm{e}}$ edition). 
Note that the French definition of á travers, although not au travers de, differs from its English and Norwegian counterparts in making no reference to either entry into nor exit from a container. It is perhaps therefore not surprising that there are only 22 tokens in the French translations $(20 \%)$ in which path is coded by à travers. Indeed French translators actually prefer to employ prepositions other than à travers to code motion 'through-ness'. Moreover, while the basic sense of 'through-ness', as coded by Norwegian giennom, is a path relation involving subcomponents of 'entrance to', 'crossing of' and 'exit from' an area or container, only the central portion of the path, denoting the crossing of the area or container, is salient in all tokens in Norwegian. (Note that in the translation of the definition of giennom above, the prepositions in and out are enclosed in brackets.) In addition, many of the French translations contain a prepositional phrase coding the area or container within which the motion event takes place (the 'site') rather than the actual path taken through the site by the mover. ${ }^{6}$ Such translations either code the path in the verb, as in $(3 \mathrm{~b})$, or leave it up to the addressee to infer the extension of the path, as in $(4 \mathrm{~b})$. There are 20 examples of the preposition dans in the French texts, as opposed to just two of in in the English ones.

(3) a. During the summer, Dina began wandering about the house. (HW 2 TE)

b. Dina recommença à circuler dans la maison cet été-là. (HW2 $\mathrm{TF}$ )

(4) a. When he walked through town ... (BHHITE)

b. Lorsqu'il déambulait dans la ville ... (BНHıTF)

In the English version of (3) the prepositional phrase codes similar information to the verb in the French version, that the path extends in a non-linear fashion throughout the space comprised by the dwelling. The prepositional phrase in the French version just denotes the locus (site) of movement. Similarly, in (4a) we are given to understand that the path extends from (near to) one side of the town to the other, while from $(4 \mathrm{~b})$ we can merely surmise that the movement took place within the confines of the town.

${ }^{6}$ Note that there are no tokens in which site is encoded by a verb in the present study, since these would be analysed as predications of location rather than motion and as such would per definition have been excluded from the data under examination. 
If an area to be crossed is very small, or even two-dimensional, the translator does not have the option of concentrating on the central portion of the path. Aurnague (2000) dubs such small areas "intrinsically medial spaces". In such cases French translators sometimes choose to code the path in the verb phrase and encode the point of boundary crossing by the preposition par, as in $(5 \mathrm{~b})$ and $(6 \mathrm{~b})$.

(5) a. Then crawled through the open window. (HW2TE)

b. Elle sortait ensuite par la fenêtre. (HW2 $\mathrm{TF})$

(6) a. One spring a duck entered the cookhouse through the open door (HW2 $\mathrm{TE})$

b. Une année, une mère eider entra par la porte ouverte du fournil ... (HW2 $\mathrm{HW}_{2}$

There are 13 instances of par in the French texts, but not a single one of English by, although the use of the latter in (6a), in which the path is coded by the verb, would result in an idiomatic English utterance. It would not, however, be possible to substitute by for through in $(5 \mathrm{a})$, in which the verb codes manner, without changing the direction of motion.

In the French versions of examples (3), (5) and (6) the path is coded by the verb rather than, or in addition to, an adverbial. This option is chosen by the French translators in just over half of the tokens ( 57 of I IO). By far the most popular verb is traverser ( 32 tokens), followed by entrer (6 tokens), franchir ( 5 tokens) and passer and sortir (3 tokens each).

Manner, like path, may also be coded by a verb, by an adverbial, or both. In example ( $\mathrm{I})$, for instance, manner is coded by the verb in both translations. In (7) and (8), on the other hand, in which the form coding manner is underlined and the form coding path in italics, manner is coded by the verb in English with path being coded in an adverbial, but in an adverbial in French with path being coded by the verb.

(7) a. Later I slipped through the door of the Grand Café ... (BHHITE)

b. Après quoi j'ai discrètement franchi la porte du Grand Café ... BHHiTF)

(8) a. She ran through the rooms wearing only pantalets ... (HW2TE)

b. En pantalon, et en courant, elle traversa la pièce ... ( $\left.\mathrm{HW}_{2} \mathrm{TF}\right)$

Figure I provides details of how often the two sets of translations code manner, path and site in verbs, adverbials or both of these. 


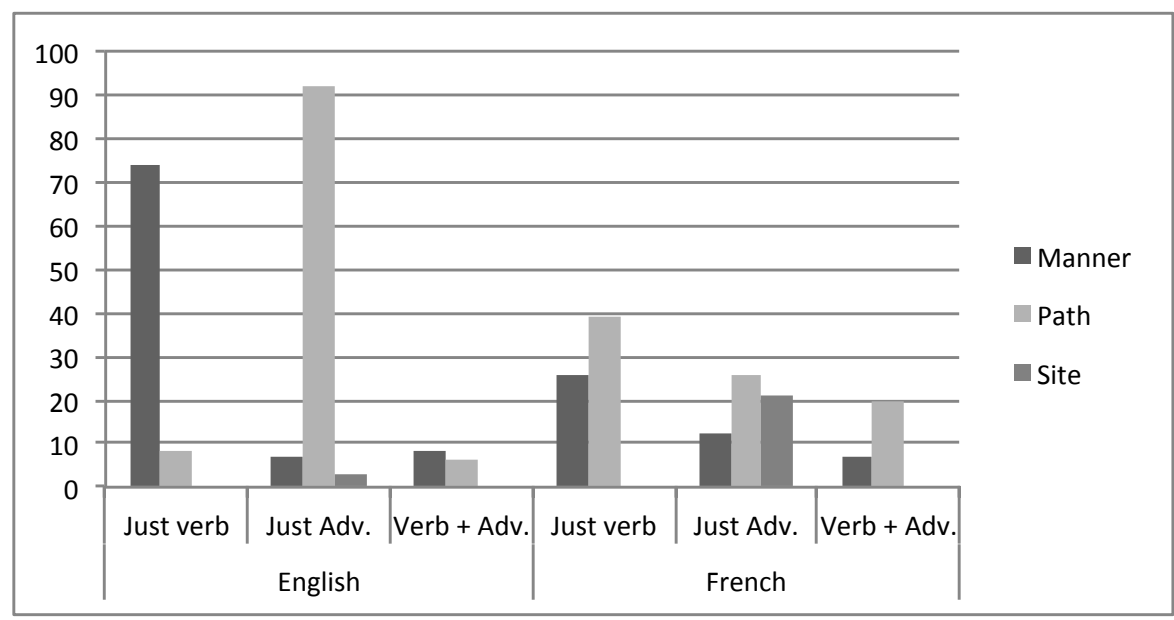

Figure 1. Manner, path and site in English and French codings of self-motion 'through-ness'.

We can see in Figure I that the English texts overwhelmingly code manner in the verb. Equally clear-cut is the tendency for path in English to be coded in an adverbial, rather than the verb. In other words, the evidence of the texts in the present study tends to confirm the view that English is indeed a satellite-framed language. The picture for French is more mixed with respect to Talmy's (2000: 22I) typological distinction. The number of tokens coding path in the verb testify to it being pathframed to a much greater extent than English, but there is a sizable minority of tokens in which manner is coded in the verb, far more than one would have expected had French been a pure verb-framed language. Rather it appears to be predominantly verb-framed, but with a number of alternative possibilities for coding manner and path, as has been pointed out by Kopecka (2006) and Pourcel and Kopecka (2005).

\section{English and French strategies for coding 'to-ness'}

The tertium comparationis for my analysis of 'to-ness' consists of codings in Norwegian of self-motion predications by means of the preposition/particle til. The definition of til in Norsk Riksmålsordbok may be translated as follows ${ }^{7}$ :

7 The definition is taken from Riksmålordbok rather than Den Norske ordboka since the latter had not reached the letter ' $t$ ' at the time of writing. The original definition reads: "brukt for å uttrykke at det styrte ord betegner bestemmelsessted, mål ell. sluttpunkt for en bevegelse, at det nevnte sted ell. område blir nådd ell. skal nås” (Norsk Riksmålsordbok: 1983) 
used to express that the word governed codes a target-place, a goal or the endpoint of a movement, so that the place or area mentioned is reached or will be reached (Norsk Riksmålsordbok 1983: my translation)

This definition of Norwegian til is very similar to that of English to in the $O E D$ and French à in Dictionnaire de l'Académie.

To: Expressing a spatial or local relation. Expressing motion directed towards and reaching: governing a n. denoting the place, thing, or person approached and reached. The opposite of from. (OED)

$\grave{A}$ introduces a complement denoting a place: $\mathrm{I}$. The place towards which there is a movment, in the direction of which one is heading. (Dictionnaire de l'Académie, neuvième édition, my translation) ${ }^{8}$

Given the similarity between the definitions of to and $\grave{a}$ and that of $t i l$, it comes as no surprise that a large number of paths coded in Norwegian by the latter are coded in a similar fashion in both English and French. (9) and (10) may serve as typical examples.

(9) a. I ran up to the window... (BHHITE)

b. Je me suis précipité à la fenêtre... (BHHITF)

(Iо) a. "Then they go to church!" Dina commented. (HW2TE)

b. "Et après, elles courent à l'église!" fut le commentaire de Dina. (HW2TF)

There are as many as 552 English tokens containing to and 354 French tokens with $\grave{a}$. The difference is partly due to a greater tendency for French to code path in the verb. However, in addition, the French translators tend to specify the extent to which the landmark has been actually reached (jusqu'à), as in (II), or whether the mover is still in the process of approaching the target (vers), as in (I2).

(I I) a. And calmly strolled across the room to the window! (HW2 TE) b. Et traversait tranquillement la pièce jusqu'à la fenêtre! (HW2 $\mathrm{TF}$ )

(I2) a. Ana raced to the jeep and returned with a small video camera ... (JG3TE)

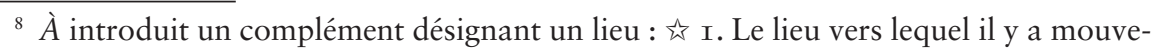
ment, vers lequel on va. (Dictionnaire de l'Académie, neuvième édition.) 
b. Ana se précipita vers la Jeep et revint avec une caméra de poing... (JG3 $\left.\mathrm{JG}_{3}\right)$

There are 40 French tokens containing the preposition jusqu'à and 90 with vers. In many of the latter there is actually no doubt that the target has been reached - thus in ( $\mathrm{I} 2 \mathrm{~b}$ ) Ana could not have got hold of the camera if she had not reached the jeep - but the French translator, focussing on the process of the progress towards the jeep, chooses the more specific (and idiomatic) proposition vers. The English texts differ markedly in the extent to which they encode the mover's actual reaching the landmark (there are 24 tokens of $u p t o$ ) and mere progress in its direction (there are only 5 tokens of towards).

Both sets of translations contain tokens in which the path is coded by both verb and adverbial, as in (I3), or verb alone, as in (I4).

(I3) a. I want you to go to La Coste, Ramon, and find De Sade. (NFITE)

b. Ramon, je veux que vous alliez à La Coste à la recherche de Sade (NFITFI)

(I4) a. Then Dagny and the boys arrived. (HW2 TE)

b. Ils arrivèrent alors, Dagny et les garçons. (HW2TF)

There are 160 constructions in English and 259 in French that resemble (13) in containing a double coding of path. ${ }^{9}$ Moreover, the construction in (I4) containing a single coding of path in the verb is much more common in French, with I I 3 tokens, compared to just I 9 in English. A further difference worth noting is that 20 of these French tokens contain a purpose adverbial, the French translator substituting the aim of the mover in seeking out some goal for the actual goal itself. This sort of usage may be seen in ( 15 ).

( 5 ) a. He returned to Mother Karen. (HW2TE)

b. Il retourna voir Mère Karen. ( $\left.\mathrm{HW}_{2} \mathrm{TF}\right)$

As for manner, underlined in the next three examples, this may also be coded by the verb, as in (I6), in an adverbial, as in (I7), or in both, as in (I 8$)$.

9 In ( I $_{3}$ ) the verbs go and aller are categorised as path verbs since they are used deictically, to encode motion away from the speaker. More often they are categorised as neutral movement verbs, as are come and venir. 
(I6) a. Then she would be running past the horses towards me... (NFITE)

b. Bientôt elle trottinera vers moi entre les croupes des chevaux ... (NFITF)

(I7) a. I'd be late if I went all the way to Majorstua on foot. (KFITE)

b. S'il fallait que j'aille à pied jusqu'à Majorstuen, j'arriverais trop tard. (KFITF)

(I 8) a. It leaped like a shaggy little animal from person to person. (HW2TE)

b. Il sautait de l'un à l'autre comme un petit animal velu. (HW2TF)

Double coding of manner as in (I8) is much less common in both languages than double coding of path. There are just I 6 tokens in English and six in French. Nor is manner coding by an adverbial alone, as in ( 17 ), frequent in either language, with 17 tokens in English and 27 in French. More common is coding of manner by the verb alone, as in (16), with 158 tokens in English and 64 in French.

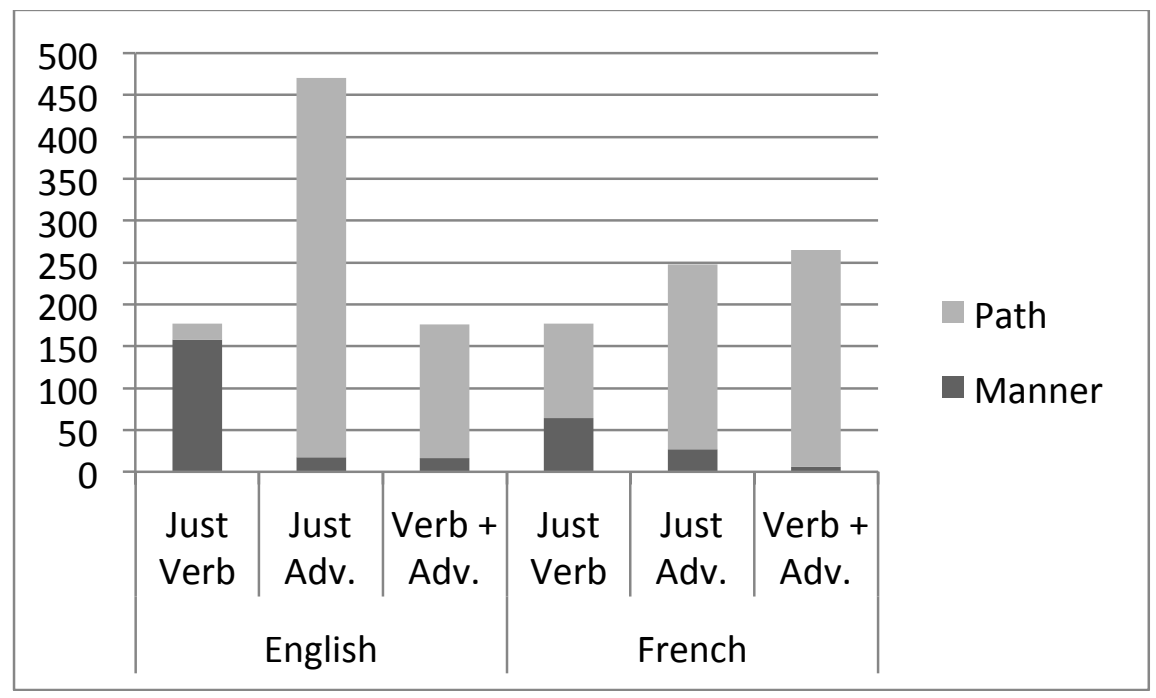

Figure 2. Coding of manner and path in English and French translations of Norwegian 'to-ness' predications. 


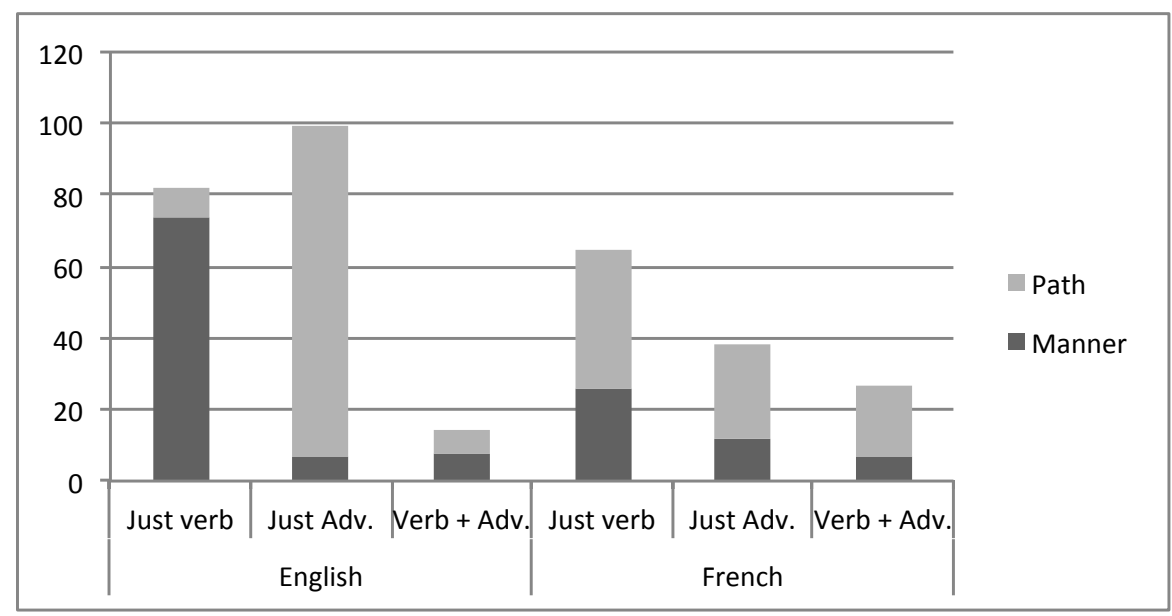

Figure 3. Coding of manner and path in English and French translations of Norwegian 'through-ness' predications.

\section{Codings of 'through-ness' and 'to-ness' compared}

This section contains a brief comparison of the English and French codings of 'to-ness' and 'through-ness' discussed in sections 3 and 4. In order to better facilitate the comparison of the two types of predication, the data for 'through-ness' in Figure I are reproduced in Figure 3 , with the tokens coding site in an adverbial omitted.

Even a cursory glance at Figures 2 and 3 will suffice to reveal that the codings of the two different sorts of motion predication, one containing a path to a target, the other a path through some sort of container, resemble one another closely in both languages with respect to the coding of manner. As for the coding of path, there is a significant difference between the two sorts of predications in both languages. This difference is related to a greater tendency to code path twice, or to split the denotation of the path between verb and adverbial in predications of 'to-ness' compared to predications of 'through-ness'. This is related to the fact that predications of 'through-ness' just evoke a medial portion of the path, the 'route', whereas predications of 'to-ness' presuppose both a route and an end-point or goal. This double coding of path [to] is illustrated in (19) and (20) and may be compared to the single coding of path [through] in (2I).

(I9) a. But he did not return to the dressing room. (HW2 TE)

b. Mais il ne retourna pas dans le cabinet. (HW2TF) 
(20) a. "Won't you come down to this bad billygoat of a man?" (HW2 $\mathrm{HE}$ )

b. "Ne peux-tu pas descendre vers ce terrible bouc de mari?" (HW2 $\mathrm{TF}$ )

(2I) a.I suggested I could walk with him through the Retiro Park. (JG3TE)

b. Je proposai de l'accompagner à travers le Retiro. (JG3TF)

In (I9) the verbs return and retourna code a path back to a previous location and the two prepositional phrases the end point of this path (dans here codes a path [into] rather than a site [in]). In (20a) the verb come codes path of motion towards the speaker, the particle down a horizontally descending path and the to phrase the end point of this path. In the corresponding French sentence it is the verb that codes the descending path, while the prepositional phrase codes the direction of the path towards its end point, rather than the end point itself. (2I), on the other hand, contains only one coding of path, referring to the medial portion, with neither the starting nor end point being specified.

Another striking difference between the tokens coding 'to-ness' and those coding 'through-ness' is the number of verbs coding neutral movement, rather than either manner or path. Such verbs include travel and voyager and non-deictic come, go, aller and venir (the deictic readings of these four verbs code path of motion in the direction of, or away from, the focused participant). There are 265 neutral movement verbs in the English translations (43\%) and 166 in the French translations $(27 \%)$ of $t i l$ compared to just 20 ( $17 \%)$ for English and I 4 ( $12 \%)$ for French in the translations of gjennom.

In English, manner is far more likely to be coded in a verb than an adverbial and path more likely to be coded in an adverbial than a verb. Moreover, when path is coded in a verb, it is likely to be coded in an adverbial as well, especially in predications of 'to-ness'. English thus conforms largely to the prototype of satellite-framed languages. French is less likely than English to code manner, but if it does do so, it resembles English in so far as it is more likely to code it in the verb than an adverbial. Thus while French does conform to some extent to the prototype of the path-framed language by coding path in the verb, it diverges from it both in preferring to code manner, if at all, in the verb and in coding path in an adverbial in addition to the verb, especially in the case of 'to-ness'. 


\section{Summary and conclusions}

In this chapter I compared codings of self-motion predications in which the path either traverses a container landmark ('through-ness') or leads up to a goal landmark ('to-ness'). The reason for choosing these two paths is that the former (potentially) involves the crossing of a boundary, while the latter does not do so. Given that French is commonly taken to avoid coding manner in the verb in boundary-crossing predications (see, for instance, Aske I989, Cappelle 20I2), one might have expected fewer such verbs in the translations of 'through-ness' predications. As we have seen in section 5 , this is not in fact the case, there being no significant difference in the encoding of manner in the verb in French renderings of the two sorts of predication.

The data for the study were taken from the Oslo Multilingual Corpus and consist of codings in English and French of the concepts of 'through-ness' and 'to-ness' as these are instantiated in translations of the same Norwegian tokens all containing adverbials with the prepositions giennom or til. With respect to predications of 'through-ness' the two languages differ in the frequency with which they employ the most frequent preposition in path adverbials. While through occurs in $83 \%$ of the English translations, à travers is only used in $20 \%$ of the French ones. In fact French translators often prefer to encode the landmark as the site within which an act of motion takes place, without specifying the nature of the path followed by the mover. Thus I $5 \%$ of tokens contain the preposition dans used to encode a site (there are three tokens in which dans encodes a path, with the sense of English into rather than in). The English translators code manner in the verb and path in an adverbial in over half of all tokens $(55 \%)$, whereas the French translators do so just $14 \%$ of the time. More common in French is double coding of path, with the verb coding the general direction of movement and the adverbial specifying this in greater detail. Also more common in French than in English are tokens in which the path is denoted by a verb such as traverser with the ground denoted by a direct object.

The translations of 'to-ness' predications differ from those of 'through-ness' in that a majority of tokens in both languages code path in an adverbial in the form of a preposition phrase containing the default prepositions to and $\grave{a}$. There are more such tokens in English than in French, the difference being due to some extent to a greater tendency for French to code path in the verb, but also to a tendency on the part of the French translators to specify the extent to which the landmark has actually been reached (jusqu'a), or whether the mover is 
still in the process of approaching the target (vers). Both languages contain a large number of constructions with a double coding of path, with French again outnumbering English. On the other hand while there are also a large number of tokens in French containing a single coding of path in the verb, this sort of coding is comparatively rare in English. Finally one may note that French translators occasionally use a purpose adverbial in place of a path one, substituting the aim of the mover in seeking out some goal for the actual goal itself.

If we compare the two types of motion predications to one another, we see that there is no significant difference between codings of 'throughness' and 'to-ness' in either language with respect to the coding of manner. On the other hand, there is a significant difference between the two types of predications in both languages in the coding of path. Another striking difference is the number of verbs coding neutral movement, which are much more common in translations of 'to-ness' predications than 'through-ness' predications. This difference reflects a difference in the original Norwegian tokens. It appears that in goal-directed predications, both the original authors and the translators focussed more narrowly on the target landmark than on the manner of the mover's reaching it or the path along which the mover travelled. Having said that, there are far more Norwegian neutral movement verbs rendered by path verbs in French than there are in English.

Turning to the question of satellite- and path-framing, we have seen that in the case of both types of path predication English seems to conform largely to the satellite framed prototype, while the picture for French is more blurred. The English texts overwhelmingly code manner in the verb. Equally clear-cut is the tendency for path in English to be coded in an adverbial, rather than the verb. As for French the number of tokens coding path in the verb testify to it being path-framed to a greater extent than English, but there is a sizable minority of tokens in which manner is coded in the verb, far more than one would have expected had French been a pure verb-framed language. Rather, French appears to be predominantly verb-framed, but with a number of alternative possibilities for coding manner and path, as has been pointed out by Kopecka (2006) and Hickmann et al. (2009).

\section{Appendix}

(I) Vi begynte å gå langsomt gjennom galleriene, og opp i andre etasje. $\left(\mathrm{JG}_{3}\right)$. 
(2) Jeg foreslo at jeg kunne følge ham gjennom Retiro-parken. $\left(\mathrm{JG}_{3}\right)$.

(3) Dina begynte å gå gjennom stuene denne sommeren. (HW2)

(4) Når han kom gående gjennom byen ... (BHHI)

(5) Og så klatre ut gjennom det åpne vinduet. (HW2)

(6) Et år kom ei ærfuglmor seg inn i eldhuset gjennom den åpne døra ... (HW 2 )

(7) Siden smøg jeg meg inn gjennom døren på Grand Kafé ... (BHHI)

(8) I bare mamelukkene sprang hun gjennom stuene ... (HW 2 )

(9) Jeg sprang til vinduet ... (BHHI)

(го) Siden fer de til kjerka! kommenterte Dina. (HW2)

(I I) Og spaserte rolig over golvet og bort til vinduet! (HW 2 )

(I2) Ana styrtet til jeepen og kom tilbake med et lite videokamera ... $\left(\mathrm{JG}_{3}\right)$

(I3) Jeg vil at de skal reise til La Coste, Ramon, og finne de Sade. (NFI)

( 4 4) Så kom de til, både Dagny og guttene. (HW2)

( 5 ) Han gikk til Mor Karen enda en gang. (HW2)

(ı6) Snart småløper hun mellom hesterompene bort til meg. (NFI)

(I7) Jeg ville komme for sent om jeg skulle ta meg helt ned til Majorstuen til fots. (KFI)

(I 8 ) Det hoppet som et lite loddent dyr, fra menneske til menneske. ( $\mathrm{HW}_{2}$ )

(19) Kan du ikke kom ned til dennan fryktelige bukken av en mann? ( $\mathrm{HW}_{2}$ )

(20) Men han gikk ikke til påkledningsværelset. (HW 2)

(2I) Jeg foreslo at jeg kunne følge ham gjennom Retiro-parken. (JG3)

\section{References}

\section{Primary}

Dictionnaire de l'Académie, huitième edition. http://artfl-project.uchicago. edu/content/dictionnaires-dautrefois

Dictionnaire de l'Académie, neuvième édition. http://atilf.atilf.fr/academieg.htm Knudsen, T., Sommerfelt A. \& Noreng H. (1983). Norsk Riksmålsordbok: Bind IV. Oslo: Kunnskapsforlaget.

Oslo Multilingual Corpus: http://www.hf.uio.no/ilos/english/services/omc/ 
Oxford English Dictionary: OED v4.0 on CD-Rom. Oxford: Oxford University Press.

Vikør, L. S. (ed.). 2002. Norsk ordbok, band IV [vol. 4]. Oslo: Det Norske Samlaget.

\section{Secondary}

Aske, J. (I989). Path predications in English and Spanish: a closer look. K. Hall, M. Meacham \& R. Shapiro (eds) Proceedings of the fifteenth annual meeting of the Berkeley Linguistics Society. Berkeley: Berkeley Linguistics Society, I-I4.

Aurnague, M. (2000). Entrer par la petite porte, passer par des chemins de traverse: à propos de la preposition par et la notion de "trajet". Carnets de grammaire. Rapport no. 7 . http://w3.erss.univ-tlse2.fr/textes/publications/ CarnetsGrammaire/carnGram7.pdf

Berman, R. A., \& Slobin, D. I. (1994). Relating events in narrative: A crosslinguistic developmental study. Hillsdale, NJ: Lawrence Erlbaum Associates.

Cappelle, B. (2OI2). English is less rich in manner-of-motion verbs when translated from French. Across Languages and Cultures, I3:2, I73-195.

Egan, T. (2OI2). Through seen through the looking glass of translation equivalence: a proposed method for determining closeness of word senses. S. Hoffman, P. Rayson \& G. Leech (eds) Corpus linguistics: Looking back - moving forward. Amsterdam: Rodopi, 4I-56.

(20I3). Tertia Comparationis in Multilingual Corpora. K. Aijmer \& B. Altenberg (eds) Advances in corpus-based contrastive linguistics. Studies in honour of Stig Johansson. Amsterdam: John Benjamins, 7-24 .

Egan, T. \& Rawoens G. (2013). "Moving over in(to) English and French". Languages in Contrast I 3:2, I93-2I I.

Filipović, L. \& Jaszczolt K. M. (eds) (2012). Space and Time in Languages and Cultures: Linguistic Diversity. Amsterdam: John Benjamins.

Hickmann, M., \& Robert S. (eds) (2006). Space in Languages: Linguistic Systems and Cognitive Categories. Amsterdam: John Benjamins.

Hickmann, M., Taranne P. \& Bonnet P. (2009). Motion in first language acquisition: Manner and Path in French and English child language. Journal of Child Language 36, 705-74I.

Jaszczolt, K. M. (2003). On translating what is said: tertium comparationis in contrastive semantics and pragmatics. K. M. Jaszczolt \& K. Turner (eds) Meaning Through Language Contrast. Vol. 2. Amsterdam: John Benjamins, $44 \mathrm{I}-462$. 
Johansson, S. (2007). Seeing through Multilingual Corpora: On the use of corpora in contrastive studies. Amsterdam: John Benjamins.

Kopecka, A. (2006). The semantic structure of motion verbs in French: Typological perspectives. M. Hickmann \& S. Robert (eds) (2006), 59-8I.

Krzeszowski, T.P. (I990). Contrasting languages: the scope of contrastive linguistics. Berlin: Mouton de Gruyter.

Lee, D. (200I). Cognitive Linguistics: an Introduction. Oxford: Oxford University Press.

Leech, G.N. (I969). Towards a semantic description of English. London: Longman.

Lindstromberg, S. (1998). English Prepositions Explained. Amsterdam: John Benjamins.

Pourcel, S. \& Kopecka A. (2005). Motion expressions in French: Typological diversity. Durham and Newcastle Working Papers in Linguistics II, I39-I 53 .

Tyler, A. \& Evans. V. (2007). The Semantics of English Prepositions: Spatial scenes, embodied meaning and cognition. Digitally printed (with corr.) ed. Cambridge: Cambridge University Press.

Slobin, D. (2006). What makes manner of motion salient? Explorations in linguistic typology, discourse and cognition. M. Hickmann \& S. Robert (eds) (2006), 83-IOI.

Talmy, L. (I99I). Path to realization: A typology of event conflation. L.A. Sutton, C. Johnson \& R. Shields (eds) Proceedings of the I7th Annual Meeting of the Berkeley Linguistics Society. University of California at Berkeley, CA: Berkeley Linguistics Society, Inc. 480-5 I9

Talmy, L. (2000). Towards a Cognitive Semantics, Volume II: Typology and Process in Concept Structuring. Cambridge MA: The MIT Press.

Viberg, A. (1998). Contrasts in polysemy and differentiation: Running and putting in English and Swedish. S. Johansson \& S. Oksefjell (eds) Corpora and Cross-linguistic Research. Amsterdam: Rodopi, 343-376.

- (2003). The polysemy of the Swedish verb komma 'come': A view from translation corpora. K.M. Jaszczolt \& K. Turner (eds) Meaning through language contrast. Vol. 2. Amsterdam: John Benjamins, 75-I05.

- (2013). Seeing the lexical profile of Swedish through multilingual corpora. The case of Swedish åka and other vehicle verbs. K. Aijmer \& B. Altenberg (eds) Advances in corpus-based contrastive linguistics. Studies in honour of Stig Johansson. Amsterdam: John Benjamins, 25-56. 